The impact of intellectual capital on performance: Evidence from the public sector

Assaad Farah

Shadi Abouzeid

American University in Dubai, United Arab Emirates

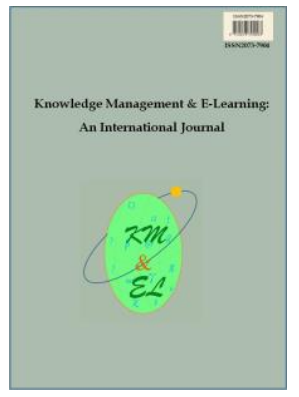

Knowledge Management \& E-Learning: An International Journal (KM\&EL) ISSN 2073-7904

Recommended citation:

Farah, A., \& Abouzeid, S. (2017). The impact of intellectual capital on performance: Evidence from the public sector. Knowledge Management \& E-Learning, 9(2), 225-238. 


\title{
The impact of intellectual capital on performance: Evidence from the public sector
}

\author{
Assaad Farah* \\ Centre for Executive Programs and Professional Services \\ American University in Dubai, United Arab Emirates \\ E-mail: afarah@aud.edu
}

\section{Shadi Abouzeid}

Centre for Executive Programs and Professional Services

American University in Dubai, United Arab Emirates

E-mail: sabouzeid@aud.edu

*Corresponding author

\begin{abstract}
This paper investigates the influence of intellectual capital on organizational performance in the public sector and studies the interconnections between intellectual capital variables within the latter setting. It follows a quantitative research approach where data was collected from 371 employees in a public entity within the Gulf Cooperation Council (GCC) region. The findings highlight the importance of human, social and organizational capital in enhancing performance in the studied organization. Furthermore, the results show that the examined forms of capital can be interconnected. These outcomes support the earlier findings on the positive impact of intellectual capital variables on performance and, provide valuable and rather rare insights on the latter interrelationships within the GCC public sector.
\end{abstract}

Keywords: Social capital; Human capital; Organizational capital; Government performance; GCC public sector

Biographical notes: Dr. Assaad Farah is an expert in Business Strategy, Human Resource Management and Knowledge Management. He presented consultancy and business research work for a wide range of organizations such as: GCC government entities, the United Nation's International Civil Aviation Organization, Bombardier Aerospace, Rogers, the International Center for Aviation Management Education and Research, and Aerlines Magazine.

Dr. Shadi Abouzeid is an expert in Business Process Re-news with a focus on improving customer service in both private and government sectors. $\mathrm{He}$ consulted with a wide variety of public and private organizations such as: GlaxoSmithKline, HSBC, Lloyds TSB, Commercial Bank of Dubai, Abu Dhabi General Secretariat of the Executive Council, Department of Municipal Affairs, LG, and Lilly. 


\section{Introduction}

Researchers claim that, in today's knowledge economy, a firm's intellectual capabilities can greatly contribute towards its competitiveness and success (Chen, Lawler, \& Bae, 2005; Choudhury, 2010; Hsu \& Sabherwal, 2011; Kamaluddin \& Rahman, 2010; Kong \& Prior, 2008; Nahapiet \& Ghoshal, 1998; Schiuma \& Lerro, 2008; Wang, 2011; Wang $\&$ Chang, 2005; Youndt \& Snell, 2004). Some scholars went to the extent of indicating that intellectual capital is the key driver of organizations (Bontis, 2001; Wang \& Chang, 2005). Such claims and indications are supported by research evidence linking key intellectual capital elements (such as human, social and organizational capital) to organizational performance (Subramaniam \& Youndt, 2005; Youndt, Subramaniam, \& Snell, 2004). Despite that, research onto the role of intellectual capital in a company's performance remains an area that requires additional empirical investigation (Hsu \& Sabherwal, 2011; Ramirez, 2010; Wang \& Chang, 2005; Youndt et al., 2004).

One of the segments in the literature that is still fairly unexplored is the function of intellectual capital in public entities. More particularly, there is little evidence in the literature on the influence of intellectual capital variables on performance within the public sector. In other words, the impact of intellectual capital on performance in the public sector is an area that is rather neglected by scholars and researchers. This is perhaps due to the belief that the 'low-competition' business context of public entities places a small weight on the quality of services, information management and customer satisfaction - all of which are elements that could greatly rely on intangible knowledge assets such as human, social and organizational capital (Carlin, Yongvanich, \& Guthrie, 2005; Ramirez, 2010; Youndt \& Snell, 2004). Nonetheless, managerial targets and techniques in several governmental departments have been, for more than a decade now, witnessing substantial transformations (Carlin et al., 2005; Hodges \& Mellet, 2002; Ramirez, 2010). In fact, many governments around the world are now increasingly focusing on factors such as service quality, information sharing and customer relations management. This implies that intellectual capital variables might also contribute to high performance in public entities and therefore, studying the intellectual capital-performance link is an area that necessitates substantial research attention.

Additionally, there is emerging evidence pointing that intellectual capital constructs can be connected to each other (Wang \& Chang, 2005). This implies that the investigation of the impact of intellectual capital variables on performance per se, might not be sufficient for a thorough understanding of how these knowledge assets can influence performance. There is a need to study the associations between different intellectual capital variables while investigating their effect on performance. Such an examination can help researchers in unlocking the mechanisms that connect intellectual capital constructs to a firm's performance. This being said, while there is some empirical support for the existence of links between intellectual capital factors, the pertinent data is primarily drawn from private organizations. Hence, little evidence has been found to demonstrate the presence of such associations in the public sector.

This study aims at making two contributions to the literature on intellectual capital. Firstly, this research conducts an empirical investigation of the influence of intellectual capital variables (human, social and organizational capital) on performance in the public sector. Secondly, this work examines the associations that could exist amongst human, social and organizational capital in public entities. 


\section{Theoretical background}

\subsection{Human, social and organizational capital}

Intellectual capital is defined as the overall knowledge, skills and capabilities that an organization can utilize to achieve competitive advantage (Nahapiet \& Ghoshal, 1998; Youndt \& Snell, 2004; Youndt et al., 2004). This study focuses on the three primary components or subcategories of intellectual capital, which are: human, social and organizational (Subramaniam \& Youndt, 2005; Youndt \& Snell, 2004; Youndt et al., 2004).

\subsubsection{Human capital}

The construct human capital is delineated as the knowledge, skills, abilities and intellect that are possessed by individuals (Becker, 1964; Schultz, 1961; Subramaniam \& Youndt, 2005; Swart, 2006; Youndt et al., 2004). Accordingly, most scholars agree that human capital is predominantly owned by the employee at the individual level rather than by the employing organization (Bontis, 1998; Davenport, 1999; Lepak \& Snell, 1999; Swart, 2006). Interestingly however, researchers argue that while the latter construct is employee-focused it highlights the gains that a firm could make from investments into its workers' knowledge, skills and abilities (Lepak \& Snell, 1999). Such an argument departs from earlier research which emphasizes more on the economic benefits that individuals could obtain from their personal drive to enhance their knowledge and capabilities (Becker, 1964). Since this study aims at studying the influence of intellectual capital variables on performance, it takes on the more contemporary view to human capital, highlighted by Lepak and Snell (1999).

\subsubsection{Social capital}

Recent work in the intellectual capital arena is emphasizing more and more on the key function that a firm's internal and external relationships could have on its performance and competitiveness (Leana \& Rousseau, 2000; Nahapiet \& Ghoshal, 1998). Such connections can include the inter-linkages that workers possess among each other and the bonds that an organization's employees can build with suppliers and customers. Therefore, there is an increasing academic interest in investigating the social relationships that a firm possesses, which are often coined in the literature under the construct social capital. Social capital is defined as an intellectual asset that includes the knowledge, skills and abilities that are embedded in an organization's network of individuals (Nahapiet \& Ghoshal, 1998; Youdnt et al, 2004). Social capital encompasses knowledge assets that are rooted within, available through and ensuing from a network of relationships and bonds (Burt, 1992; Coleman, 1988; Youndt et al., 2004). Therefore, this form of capital projects the extent to which a firm can leverage knowledge between networks of workers, clients, suppliers and/or partners (Youndt \& Snell, 2004).

\subsubsection{Organizational capital}

Organizational capital is the form of capital that is not entrenched in people or networks of relations (Youndt \& Snell, 2004). It is defined as the codified knowledge and experiences that a firm is maintaining in factors like processes, manuals, patents and databases (Subramaniam \& Youndt, 2005; Youndt \& Snell, 2004; Youndt et al., 2004). 
Accordingly, organizational capital can be categorized as the type of intellectual capital that is owned by the firm and that is safeguarded within the walls of the organization when changes in the workforce occur (Walsh \& Ungson, 1991).

After defining human, social and organizational capital, the next section discusses the impact that these three elements of intellectual capital could have on organizational performance.

\subsection{The impact of intellectual capital on performance}

The introductory section of this paper has highlighted the central function that intellectual capital could have in achieving high performance and competitiveness (Kang \& Snell, 2009; Kang, Morris, \& Snell, 2007; Subramaniam \& Youndt, 2005; Youndt et al., 2004). This section discusses the impact of each subcategory of intellectual capital on organizational performance.

\subsubsection{The impact of human capital on organizational performance}

The knowledge, skills and abilities that employees possess could assist organizations in increasing their organizational performance (Kang et al., 2007; Subramaniam \& Youndt, 2005; Youndt et al., 2004). For example, quality scholars posit that employee knowledge can assist in developing new quality improvement techniques that could enhance product and/or service reliability and in turn, customer satisfaction (Deming, 1986). Moreover, workers' creativity can be central to the success of innovative projects (Kang \& Snell, 2009). As well, employees who possess strong experience in a certain field could help in optimizing pertinent processes, which could assist in enhancing service quality and/or could help reducing operating costs (Subramaniam \& Youndt, 2005).

\subsubsection{The impact of social capital on organizational performance}

Knowledge that is stored and exchanged in networks of relations between different members can assist organizations in enhancing their performance and competitiveness (Subramaniam \& Youndt, 2005). Social capital can help developing open communication channels among employees and between workers and, customers and suppliers (Youndt et al., 2004). This could promote the synthesis and processing of critical information, which could, for instance, help a firm in reducing its costs or enhancing the quality of its products/services (Kang \& Snell, 2009; Subramaniam \& Youndt, 2005). Moreover, the transfer of knowledge through social capital can help promoting creativity, innovation and problem solving (Youndt \& Snell, 2004). This in turn, could enhance customer relations, the development of new products/services and quality levels (Adler \& Kwon, 2002; Kang et al., 2007; Youndt et al., 2004).

\subsubsection{The impact of organizational capital on organizational performance}

Scholars indicate that much like human and social capital, organizational capital can play an important role in enhancing organizational performance (Subramaniam \& Youndt, 2005; Youndt et al., 2004). For instance, organizational capital can help reducing a firm's costs. As the latter construct involves the storage of experiences and knowledge from previous projects in processes and manuals, organizational capital can help decreasing error and operating expenses (Youndt et al., 2004). Additionally, procedures and databases that encompass knowledge gathered from earlier designs or business cases 
could help reducing the time required to produce similar designs or solve analogous problems (Kang \& Snell, 2009). Other than cost reduction, organizational capital can as well, help enhancing customer satisfaction. In effect, databases that encompass information on customer preferences could help an organization in providing products and services that cater to its target customers' needs (Youndt et al., 2004).

\subsection{The interconnections between human, social and organizational capital}

While human, social and organizational capital can impact organizational performance, there are arguments and findings in the intellectual capital literature indicating that the latter forms of capital could be related to one another (Wang \& Chang, 2005). The subsequent subsections shed more light on these types of interactions.

\subsubsection{The link between human capital and, social and organizational capital}

The aforementioned section indicated that social and organizational capital can impact organizational performance. Interestingly, researchers posit that human capital can contribute to the development of the two latter forms of intellectual capital (Kang et al., 2007; Youndt et al., 2004). In relation to the impact of human capital on social capital, Kang et al. (2007) indicate that based on the features of human capital of an organization, common component knowledge might develop between employees. In particular, when workers have operated in common technical roles and consequently, have built shared experiences this could assist in developing common languages (Kang et al., 2007), which could promote social capital (Nahapiet \& Ghoshal, 1998). Moreover, workers' interpersonal skills can facilitate the development of collective work between members within firms and can promote relationships between a company's members and different outside stakeholders (Leana \& Van Buren, 1999; Youndt \& Snell, 2004). In parallel and as indicated at the start of this paragraph, human capital can also impact a company's organizational capital. In other words, workers' skills and knowledge can contribute to the development of a firm's databases, manuals and procedures (Hansen, Nohria, \& Tierney, 1999; Youndt \& Snell, 2004). For example, the experience that employees have gathered from earlier projects can assist in the creation or optimization of a firm's procedures (Youndt \& Snell, 2004). Similarly, employees' experiences and knowledge can help updating a firm's databases (Youndt et al., 2004).

In parallel, whereas human capital could help promoting social and organizational capital, it seems that the latter two forms of capital could as well, help developing a firm's human capital. To help supporting this argument, it is important first to present the two main categories of knowledge: tacit and codified. Researchers have classified knowledge depending on the extent to which it can be capture and articulated in documents (Boh, 2007; Nonaka, 1994). Codified knowledge is delineated as the form of knowledge 'that is transmittable in formal and systematic language' (Nonaka, 1994, p. $160)$, and that can be transcribed and stored in libraries, manuals, databases and processes (Cowan, David, \& Foray, 2000; Nonaka, 1994). On the other hand, tacit knowledge is defined as the type of knowledge that 'has a personal quality, which makes it hard to formalize and communicate' (Nonaka, 1994, p. 16). Therefore, this form of knowledge is not easily stored in transmitted in processes, document and manuals (Boh, 2007; Cowan et al., 2000; Spender, 1996).

Authors posit that tacit knowledge is commonly understood and exchanged through social relationships and interactions between a firm's members (Boh, 2007; Hansen et al., 1999; Laursen \& Mahnke, 2001; Nonaka, 1994; Preece, 2003). In effect, 
due to the nature of tacit knowledge, it is highly connected to the body and mind of the individuals who possess this knowledge. Hence, the best medium to exchange and learn tacit knowledge between employees is the network of interconnections that could exist among individuals (i.e. social capital) (Boh, 2007). Accordingly, it appears that social capital can help developing tacit knowledge in individuals and therefore, could promote human capital.

In parallel, as codified knowledge is knowledge that is scripted, it appears that documents (such as an organization's procedures, manuals and databases) could best help understanding and transmitting this form of knowledge (Hansen et al., 1999; Subramaniam \& Youndt, 2005). Consequently, a firm's organizational capital could form an effective medium through which its employees could learn and exchange codified knowledge (Boh, 2007; Subramaniam \& Youndt, 2005). Accordingly, it could be argued that organizational capital could contribute to the development of human capital.

\subsubsection{The interconnections between social and organizational capital}

Perceived quality and value of products and/or services can have an influence on customer satisfaction (Fornell, Johnson, Anderson, Cha, \& Bryant, 1996; Zeithaml, Bitner, \& Gremler, 1996). Scholars posit that the quality and value of products/services can be enhanced through the presence of strong work procedures and processes (Wand and Chang, 2005). In turn, an increase in customer satisfaction could strengthen the relationships between a firm and its clients (ibid). In addition, work processes can include routines that encourage workers and departments inside an organization to collaborate on certain tasks and activities. Therefore, it could be argued that organizational capital could promote interactions among a firm's members. Accordingly, as social capital encompasses the connections that a company has with its clients and the relationships that members of a company could possess amongst each other, one could argue that organizational capital could impact social capital. In turn, innovative ideas and work experiences that are exchanged between workers in networks of relations within a firm could contribute to the development of work processes and procedures (Wang \& Chang, 2005). Hence, one could also argue that social capital can impact organizational capital.

After shedding some light on the role that intellectual capital variables could play in enhancing a firm's performance and subsequent to discussing the interconnections that could exist amongst human, social and organizational capital, the next section highlights the function that intellectual capital could have inside the public sector.

\subsection{Human, social and organizational capital and performance in the public sector}

Kong and Thomson (2009) indicate that in today's knowledge economy the combined knowledge of a firm plays a significant function in its competitiveness and success. As highlighted in this article, intellectual capital encompasses the collective knowledge of an organization, predominantly represented in its human, social and organizational capital. While intellectual capital was commonly seen as a key asset for private more than public entities, there are indications pointing that such a view may no longer hold (Chen, 2008; Kong \& Prior, 2008; Schiuma \& Lerro, 2008). In effect, the public sector has been undergoing great reforms and is increasingly adopting management techniques and business objectives that are rather similar to those of private organizations (Carlin et al., 2005; Hodges \& Mellet, 2002; Mouritsen, Thorbjørnsen, Bukh, \& Johansen, 2004). In particular, nowadays, the public sector is characterized by a greater focus on services 
mainly, improved response capacity to requirements of the users of services and better display of results to citizens (Ramirez, 2010). The latter factors can greatly rely on strong procedures and high levels of human capital (Guimet, 1999; Youndt et al., 2004). Moreover, much like in private firms, public organizations are more and more depending on a strong management of data and information (Pérez \& Fernández, 2003; Ramirez, 2010). Consequently, the exchange of knowledge between public sector employees and, among public entities and citizens can be significant to the performance of the public sector.

Nonetheless, while the examination of the literature points that intellectual capital constructs might play a role in the performance of public entities, research in this area is still in its embryonic stages (Carlin et al., 2005; Chen, 2008; Guimet, 1999; Hodges \& Mellet, 2002; Kong \& Prior, 2008; Mouritsen et al., 2004; Ramirez, 2010; Schiuma \& Lerro, 2008; Subramaniam \& Youndt, 2005; Youndt \& Snell, 2004; Youndt et al., 2004). Particularly, there is little empirical evidence supporting the influence of intellectual capital variables on performance in the public sector. In relation to that and in its attempt to contribute to the intellectual capital literature, this paper examines the subsequent three propositions:

Proposition1: Human capital positively affects performance in the public sector.

Proposition2: Social capital positively affects performance in the public sector.

Proposition3: Organizational capital positively affects performance in the public sector.

Moreover, while the presence of interconnections between intellectual capital variables still needs more research in private companies, there are, as discussed in the aforementioned section, arguments and findings that point towards a possible interrelationship between intellectual capital categories in these types of firms (Boh, 2007; Fornell et al., 1996; Hansen et al., 1999; Leana \& Van Buren, 1999; Nonaka, 1994; Preece, 2003; Subramaniam \& Youndt, 2005; Wang \& Chang, 2005; Youndt \& Snell, 2004; Zeithaml et al., 1996). As discussed earlier in this section, many public entities are now adopting similar management techniques as in private companies. Accordingly, it could be argued that it is also likely that there exist interconnections between intellectual capital elements in public organizations. In relation to that, this papers tests the following propositions:

Proposition4: Human capital is positively related to social capital in the public sector.

Proposition5: Human capital is positively related to organizational capital in the public sector.

Proposition6: Organizational capital is positively related to social capital in the public sector.

The subsequent section presents the methodological approach adopted in this research to test the aforementioned six propositions.

\section{Method}

Data in this study was collected from two entities of a public organization in the GCC region. The first entity is a regulatory body that mainly deals with issuing laws and regulations for other government entities. Most of those laws directly impact citizens' lives and are focused on service delivery, with the aim of improving efficiency and 
effectiveness of services. The second entity is a central government unit that oversees the strategic planning, budgeting and performance management cycle for all government entities. The core of its operation is to promote the concepts of business excellence through yearly assessments and improvement plans.

A self-administered questionnaire was used to collect data in this study. The questionnaire encompassed a cover letter introducing the research and its objectives. The cover page as well, disclosed the identity of the researchers and, promised confidentiality and anonymity to the respondents. To ensure efficiency in the data collection stage, the data was gathered in an automated manner, using the NEPO software. NEPO is a tool that can be installed onto an organization's servers and enables a web posting of the survey. This helps in securely storing the data within the entity and hence, helps avoiding the breach of confidential information, which could result from using publicly available engines.

An internal communication was sent to all employees of the two studied entities via an email, which encompassed a link to the survey. Entity 1 contained 199 full time workers, 174 of which accepted to participate in the survey. Entity 2 encompassed 420 full time employees, of which 197 accepted to complete the survey. In addition to information about the study, the email reassured employees that their responses would remain confidential and that data would be aggregated together so that no individual's responses could be identified. It is worth mentioning that the survey was drafted in English and that all participating employees were fluent in the latter language - fluency in English is an employment requirement in the two studied entities. Moreover, the usage of the NEPO software along with the high degrees of confidentiality that were assured to all participants, are believed to have reduced bias in the collected data.

\subsection{Measurement}

The survey items for the main variables in this study were formulated from previous research. Multi-item scales were adopted for all of the key variables in order to obtain a comprehensive evaluation of these constructs. This falls in line with Nunnally (1978) and Peter (1979) argument which points that multi-scales are necessary for valid measurement of factorially complex constructs.

The intellectual capital variables were measured by adopting the multi-item scale measure developed by Youndt and Snell (2004). The scale consists of 14 items designed to measure 3 subcategories of intellectual capital; human, organizational and social capital. Youndt and Snell (2004) tested the convergent and discriminant validity of this scale by performing confirmatory maximum likelihood factor analysis. Their analysis confirmed the three aspects of intellectual capital.

In particular, Human Capital was measured using five-items tapping the overall skill, expertise, and knowledge levels of an organization's workers. Youndt and Snell (2004) reported an alpha coefficient of 0.81 for this measure. An example of these items is 'our employees are highly skilled'.

Organizational Capital was assessed using four items measuring an 'organization's ability to appropriate and store knowledge in physical organizationallevel repositories such as databases, manuals and patents' (Youndt \& Snell, 2004, p. 347) with a coefficient alpha of .62. An example of these items is 'much of our organization's knowledge is contained in manuals, databases, etc'. 
In relation to Social Capital, this construct was captured using five items reflecting 'an organization's overall ability to share and leverage knowledge among and between networks of employees, customers, suppliers, alliance partners, and the like' (Youndt \& Snell, 2004, p. 347), with an alpha of .88. A sample of these items is 'our employees interact and exchange ideas with people from different areas of the company'.

With regard to Organizational Performance, this variable was assessed through employees' perception of their department's performance; rather than collecting financial measures. Whereas the use of perceptions of performance in place of measuring the actual performance can present limitations through increased error in the measurement, such a measure is commonly adopted in earlier studies. Most importantly, Dollinger and Golden (1992) have demonstrated that measures of perceived organizational performance have a positive association with objective measures of organizational performance. In this study, self-reported perceptions of performance are obtained through the use of a multidimensional measure adapted from Gould-Williams (2003). This measure evaluated perceptions of value for money, service quality and service efficiency of a public entity, and has an alpha equal to .87. An example of these items is 'Service users have very little cause to complain'.

\section{Analysis}

All the variables used in this paper were normally distributed. Table 1 highlights the mean, standard deviation, and reliability alpha coefficient of the variables.

Table 1

Variables description

\begin{tabular}{ccccc}
\hline Variables & Items & Alpha & $\begin{array}{c}\text { Standard } \\
\text { Deviation }\end{array}$ & Mean \\
\hline Human Capital & 6 & 0.942 & 1.69608 & 1.085 \\
Social Capital & 4 & 0.866 & 1.15467 & 1.312 \\
$\begin{array}{c}\text { Organizational } \\
\text { Capital }\end{array}$ & 4 & 0.901 & 1.44019 & 1.969 \\
$\begin{array}{c}\text { Organizational } \\
\text { Performance }\end{array}$ & 5 & 0.731 & 1.01467 & 1.427 \\
\hline
\end{tabular}

To test the hypotheses that the different intellectual capital variables positively affect organization performance this study used regression analysis. The results are reported in Table 2. The findings show that the human capital has a positive effect on organization performance $($ Beta $=.576 \mathrm{p}<0.001)$. In addition, social capital has a positive effect on organization performance (Beta $=.605 \mathrm{p}<0.001$ ). Moreover, as expected, the regression analysis output shows that organization capital has a positive effect on organizational performance $($ Beta $=.598 \mathrm{p}<0.001)$. Accordingly, the findings show that the effect of human, social and organization capital on organizational performance, when studied separately, was positive with beta and significance level being respectively 0.576 $\mathrm{p}<0.001,0.605 \mathrm{p}<0.001$ and $0.598 \mathrm{p}<0.001$. (see Table 3) 
Table 2

Regression analysis - The impact of intellectual capital on performance

\begin{tabular}{lccc}
\hline & $\begin{array}{l}\text { Organization } \\
\text { Performance } \\
\text { Standardized Beta }\end{array}$ & $\begin{array}{l}\text { Organization } \\
\text { Performance } \\
\text { Standardized Beta }\end{array}$ & $\begin{array}{l}\text { Organization } \\
\text { Performance } \\
\text { Standardized Beta }\end{array}$ \\
\hline $\begin{array}{l}\text { Human Capital } \\
\text { Social Capital }\end{array}$ & $0.576^{* * *}$ & $0.605^{* * * *}$ & \\
$\begin{array}{l}\text { Organization } \\
\text { Capital }\end{array}$ & & & $0.598^{* * *}$ \\
R square & 0.332 & 0.365 & 0.358 \\
F & $177.169^{* * *}$ & $204.427^{* * *}$ & $200.122^{* * *}$ \\
\hline
\end{tabular}

Note. $* p<.05 . * * p<.01 . * * * p<.001$

In addition to the regression analysis conducted that showed the positive effect of the intellectual capital constructs on organization performance, this research tested the pairwise correlation of those intellectual capital variables. The results demonstrate that social and human capital are correlated with $\mathrm{r}$ being $0.707 \mathrm{p}<0.001$, while organizational and social capital are correlated with $r$ being $0.700 \mathrm{p}<0.001$. The third correlation tested was organizational and human capital that showed $\mathrm{r}$ being $0.577 \mathrm{p}<0.001$.

Table 3

Correlation output: Human, social and organizational capital

\begin{tabular}{lcc}
\hline & \multicolumn{2}{c}{ Pearson Correlation } \\
Variables & Human Capital & Social Capital \\
\hline Social Capital & $0.707 * * *$ & $0.700 * * *$ \\
Organizational Capital & $0.577 * * *$ & 0.000 \\
\hline
\end{tabular}

Note. ${ }^{*} \mathrm{p}<.05 . * * \mathrm{p}<.01 . * * * \mathrm{p}<.001$

\section{Discussion, limitations and future research}

The outcomes of this study support earlier arguments indicating that intellectual capital variables (human, social and organizational capital) can have a positive impact on organizational performance (Kang et al., 2007; Subramaniam \& Youndt, 2005; Youndt \& Snell, 2004; Youndt et al., 2004).

Moreover, the results of the empirical investigation conducted in this paper support its propositions pointing that human, social and organizational capital can have a positive impact on organizational performance in the public sector. As argued earlier, many public entities are undergoing substantial reforms and are now adopting management techniques and objectives that greatly resemble those of the private sector, such as: increased focus on service quality, on citizens' satisfaction and on the management of information (Carlin et al., 2005; Hodges \& Mellet, 2002; Mouritsen et al., 2004; Ramirez, 2010). As these latter factors can greatly depend on the presence of strong human, social and organizational capital within business entities (Subramaniam \& 
Youndt, 2005; Youndt et al, 2004), it is not surprising that the studied knowledge assets were found to affect performance in the examined public entities. Furthermore, while there are emerging findings on the interrelationships between intellectual capital constructs in the private sector, the outcomes of this paper offer key information on such associations in the public sector. The results of this study propose that there could also be positive relationships between intellectual capital variables (human, social and organizational capital) in public entities.

Most interestingly, the outcomes of this study offer valuable insights onto the role of intellectual capital in enhancing performance within public entities in the GCC countries. In effect, the governments in the Arabian Gulf nations have been increasingly stressing on the usage of innovation and knowledge management assets within governmental organizations. Yet, practitioners have argued the effectiveness of a knowledge management approach within the public sector in the GCC. Furthermore, there exists little empirical evidence supporting the function of intellectual capital within this context. To that, this paper contributes to knowledge by demonstrating a positive role for intellectual capital in the GCC government.

In sum, this paper highlights the importance of studying intellectual capital factors in future academic research investigating performance in the public sector and more particularly in the GCC context. As well, the outcomes of this paper indicate that upcoming researches can benefit from conducting a more macro investigation of the connections linking intellectual capital variables to performance in the public sector. This could be achieved by testing the direct as well as the indirect impact of human, social and organizational capital on the performance of public entities - such as proposed in Fig. 1 .

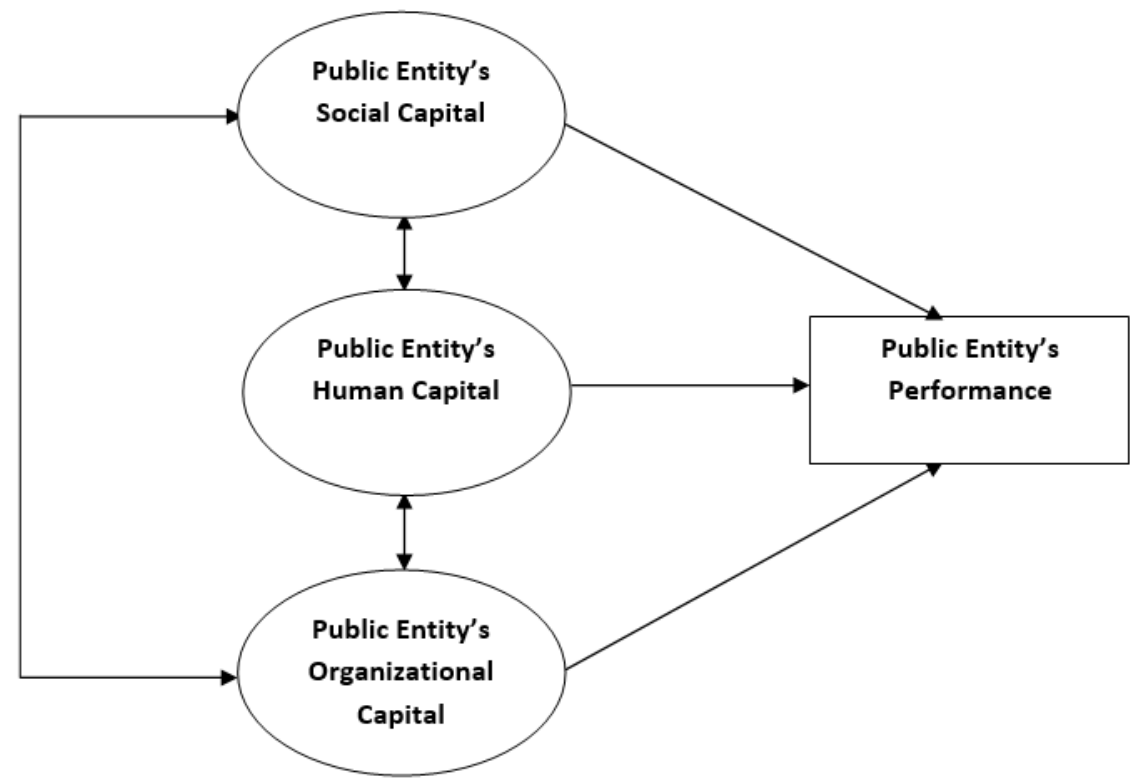

Fig. 1. Proposed model

It is worth noting here that this paper uses correlation analysis to study the interconnections between human, social and organizational capital. Future work studying the latter interrelationships could benefit from measuring the cause and effect between 
human, social and organizational capital. This could be obtained by using the partial least squares method (Wang \& Chang, 2005). This is a variance-based structure equation modeling techniques that could assess cause and effect between variables while avoiding multi-collinearity issues which could arise from using regression analysis.

Furthermore, the aim of this study is not to produce generalizable results, but rather to offer evidence that supports its propositions. In effect, this research was conducted within two particular entities in the public sector within the Arabian Gulf. The nature of work inside these two entities might have placed great emphasis on the sharing of information between individuals, on work processes, and on the level of knowledge of individual employees; which perhaps explains the importance of human, social and organizational capital in achieving higher performance. Consequently, the propositions of this study might not hold in other public entities, which could be located in other geographical regions and most importantly, which might have different managerial targets and techniques. Therefore, future researches should investigate this paper's proposed model in various settings within the public sector. Such examinations could help depicting the contextual factors (such as managerial techniques, government objectives and employee characteristics) that could influence the interconnections proposed in this study.

In the end, this paper's results point that managers within governmental entities might need to review their business strategies in order to ensure that enough time and investment is directed towards the development of intellectual capital. As knowledge assets appear to be interconnected, practitioners in the public sector might need to concurrently emphasize on the development of their unit's human, social and organizational capital.

\section{References}

Adler, P. S., \& Kwon, S. W. (2002). Social capital: Prospects for a new concept. Academy of Management Review, 27, 17-40.

Becker, G. S. (1964). Human capital: A theoretical and empirical analysis with special reference to education. New York: Columbia University Press.

Boh, F. W. (2007). Mechanisms for sharing knowledge in project-based organizations. Information and Organization, 17, 27-58.

Bontis, N. (1998). Intellectual capital: An exploratory study that develops measures and models. Management Decision, 36(2), 63-76.

Bontis, N. (2001). Assessing knowledge assets: A review of the models used to measure intellectual capital. International Journal of Management Reviews, 3, 41-60.

Burt, R. S. (1992). Structural holes: The social structure of competition. Cambridge, MA: Harvard University Press.

Carlin, T. M., Yongvanich, K., \& Guthrie, J. (2005). Public sector performance reporting: The intellectual capital question? In Proceedings of 9th International Research Symposium on Public Management. Bocconi University, Milan.

Chen, S. J., Lawler, J. J., \& Bae, J. (2005). Convergence in human resource systems: A comparison of locally owned and MNC subsidiaries in Taiwan. Human Resource Management, 44(3), 237-256.

Chen, Y. S. (2008). The positive effect of green intellectual capital on competitive advantages of firms. Journal of Business Ethics, 77(3), 271-286.

Choudhury, J. (2010). Performance impact of intellectual capital: A study of Indian it sector. International Journal of Business and Management, 5(9), 72-80.

Coleman, J. C. (1998). Social capital in the creation of human capital. American Journal 
of Sociology, 94, 95-120.

Cowan, R., David, P. A., \& Foray, D. (2000). The explicit economics of knowledge codification and tacitness. Industrial and Corporate Change, 9(2), 211-253.

Davenport, T. O. (1999). Human capital: What it is and why people invest it. San Francisco, CA: Jossey-Bass.

Dollinger, M. J., \& Golden, P. A. (1992). Interorganizational and collective strategies in small firms: Environmental effects and performance. Journal of Management, 18(4), 695-715.

Fornell, C., Johnson, M. D., Anderson, E. W., Cha, J., \& Bryant, B. E. (1996). The American customer satisfaction index: Nature, purpose, and findings. Journal of Marketing, 60(4), 7-18.

Gould-Williams, J. (2003). The importance of HR practices and workplace trust in achieving superior performance: A study of public-sector organizations. International Journal of Human Resource Management, 14, 28-54.

Guimet, J. G. (1999). Eficacia, eficiencia y gestio'n de lo intangible: El capital intelectual en las organizaciones y Administración Pu' blica. Revista Catastro, 35, 49-59.

Hansen, M. T., Nohria, N., \& Tierney, T. (1999). What's your strategy for managing knowledge? Harvard Business Review, 77(2), 106-116.

Hodges, R., \& Mellet, H. (2002). Testing the new public management: Accounting regulation and due process. Paper presented at the 25th European Accounting Association Congress. Copenhagen.

Hsu, I. C., \& Sabherwal, R. (2011). From intellectual capital to firm performance: The mediating role of knowledge management capabilities. IEEE Transactions on Engineering Management, 58(4), 626-642.

Kamaluddin, A., \& Rahman, R. A. (2010). The moderating effect of organization culture on intellectual capital and organizational effectiveness relationships. In Proceedings of the International Conference on Intellectual Capital, Knowledge Management \& Organizational Learning.

Kang, S. C., Morris, S. S., \& Snell, S. A. (2007). Relational archetypes, organizational learning, and value creation: Extending the human resource architecture. Academy of Management Review, 32, 236-256.

Kang, S. C., \& Snell, S. A. (2009). Intellectual capital architectures and ambidextrous learning: A framework for human resource management. Journal of Management Studies, 46, 65-92.

Kong, E., \& Prior, D. (2008). An intellectual capital perspective of competitive advantage in non-profit organisations. International Journal of Non-profit and Voluntary Sector Marketing, 13(2), 119-128.

Kong, E., \& Thomson, S. B. (2009). An intellectual capital perspective of human resource strategies and practices. Knowledge Management Research \& Practice, 7(4), 356-364.

Laursen, K., \& Mahnke, V. (2001). Knowledge strategies, firm types, and complementarity in human-resource practices. Journal of Management and Governance, 5, 1-27.

Leana, C. R., \& Rousseau, D. M. (2000). Relational wealth: Advantages of stability in a changing economy. New York: Oxford University Press.

Leana, C. R., \& Van Buren, H. J. (1999). Organizational social capital and employment practices. Academy of Management Review 24(3), 538-555.

Lepak, D. P., \& Snell, S. A. (1999). The human resource architecture: Toward a theory of human capital allocation and development. Academy of Management Review, 24, 3148.

Mouritsen, J., Thorbjørnsen, S., Bukh, P. N., \& Johansen, M. R. (2004). Intellectual 
capital and new public management: Reintroducing enterprise. The Learning Organization, 11(4/5), 380-392.

Nahapiet, J., \& Ghoshal, S. (1998). Social capital, intellectual capital, and the organizational advantage. Academy of Management Review, 23(2), 242-266.

Nonaka, I. (1994). A dynamic theory of organizational knowledge creation. Organization Science, 5, 14-37.

Nunnally, J. C. (1978). Psychometric theory. New York: McGraw-Hill.

Pérez, M. D. C. C., \& Fernández, M. S. (2003). La evaluación del capital intelectual en la administración Local. Auditoría Pública, 29, 32-41.

Peter, P. J. (1979). Reliability: A review of psychometric basics and recent marketing practices. Journal of Marketing Research, 16, 6-17.

Preece, J. (2003). Tacit knowledge and social capital: Supporting sociability in online communities of practice. In Proceedings of I-KNOW'03, 3rd International Conference on Knowledge Management. Graz, Austria.

Ramirez, Y. (2010). Intellectual capital models in Spanish public sector. Journal of Intellectual Capital, 11(2), 248-264.

Schiuma, G., \& Lerro, A. (2008). Intellectual capital and company's performance improvement. Measurement Business Excellence, 12(2), 3-9.

Schultz, T. W. (1961). Investment in human capital. The American Economic Review, 51, $1-17$.

Spender, J. C. (1996). Making knowledge the basis of a dynamic theory of the firm. Strategic Management Journal, 17(S2), 45-62.

Subramaniam, M., \& Youndt, M. A. (2005). The influence of intellectual capital on the types of innovative capabilities. Academy of Management Journal, 48(3), 450-463.

Swart, J. (2006). Intellectual capital: Disentangling an enigmatic concept. Journal of Intellectual Capital, 7(2), 136-159.

Walsh, J. P., \& Ungson, G. R. (1991). Organizational memory. Academy of Management Review, 16, 57-91.

Wang, M. S. (2011). Intellectual capital and firm performance. In Proceedings of the Annual Conference on Innovations in Business \& Management. London, UK.

Wang, W.Y., \& Chang, C. (2005). Intellectual capital and performance in causal models: evidence from the information technology industry in Taiwan. Journal of Intellectual Capital, 6(2), 222-236.

Youndt, M. A., \& Snell, S. A. (2004). Human resource configurations, intellectual capital, and organizational performance. Journal of Managerial Issues, 16(3), 337-360.

Youndt, M. A., Subramaniam, M., \& Snell, S. A. (2004). Intellectual capital profiles: An examination of investments and returns. Journal of Management Studies, 41(2), 335362.

Zeithaml, V. A., Bitner, M. J., \& Gremler, D. D. (1996). Services marketing: Integrating customer focus across the firm. New York, NY: McGraw-Hill. 